日心第71回大会 (2007)

第2日 9 月19日（水） $10: 00 \sim 12: 006308$

\title{
WS056 道徳的感情と行動
}

\author{
一 恥 (shame) · 羞恥感 (embarrassment) - 罪悪感 (guilt) -
}

\begin{tabular}{|c|c|c|}
\hline 企＼cjkstart画 & 聖心女子大学 & 理津子 \\
\hline 画 & お茶の水女子大学 & 藤澤 \\
\hline 会 & お茶の水女子大学 & 藤澤 \\
\hline 舌題提供者 & 聖心女子大学 & 薊 理津子 \\
\hline & 広島大学 & 樋口 匡貴 \\
\hline 是供者 & 神戸学院大学 & 稲葉小由紀 \\
\hline 借者 & 東洋大学 & 榎本 淳子 \# \\
\hline & 聖心女子大学 & 菅原 \\
\hline 侖 & 東京文化短期大学 & 永房 \\
\hline
\end{tabular}

\section{概 要}

近年、社会の変化に伴い、犯罪や青少年の非行が問題化されており、道徳性（moral）の低下という観点か ら述べられることが少なくない。これまで道徳性は、研究者により認知、情動、行動もしくはパーソナリテ イという異なる側面から異なるアプローチを用いて研究されている。本WS では、道徳性を「人のふみ行うべ き道 (広辞苑)」と広く定義し、まだあまり検討されていない情動と行動について、情動的側面からアプロー チ寸る研究者に最新の研究データとともに話題提供していただく。具体的には、恥（shame）、羞恥感 (embarrassment) と罪悪感（guilt）を取り上げる。最後に、感情が社会的判断にどのような作用をもたら し、また、その社会的判断によって導かれた行動について紹介していただく。 